\title{
The Backgrund in Entreneurship Research Previously Done
}

\section{Lei Shen}

Accounting School, Tong Ling University, Tong Ling, 244000, Anhui China.

E-mail: s15169128@sina.com

Fund project:The innovation project of university students in Anhui(No:AH20140383095)

Abstract: Today, entrepreneurship is regarded as one of the best economic development strategies to develop the country's economic growth and sustain the country's competitiveness in facing the increasing trends of globalization The research is a study of the background in entrepreneurship research previously done and findings.

Keywords: Undergraduates in China; Entrepreneur; Entrepreneurship

\section{Introduction}

In China, one-third of the new entrepreneurs are younger than 30 years old. More than 60 percent of these entrepreneurs whose ages range from 18 to 29 year, have expressed that they want to own their own business. The self-employed students are ubiquitous in higher education. The students prefer to be self-employed than live on campus, to study full time and attend a four-year college or university. The students' self-employment status is preferred regardless of the type of institution they attend, their age or family responsibilities, or even their family income or educational and living expenses. Being self-employed while enrolled is perhaps the single most common major activity among Chinese diverse undergraduate population.

\section{Research background and research status at home and abroad}

\subsection{Entrepreneur}

Entrepreneurship is a worldwide phenomenon with economic growth across the globe that is positively compressed by the emergence of new and innovative business start-ups. These new small businesses play a significant role in job creation, influencing politicians to recognize and support entrepreneurial start-up activity due to its positive contribution to the economy. Historically, economists have supported the view that entrepreneurship is responsible for economic expansion (Cole, 1965; Weber, 1930) due to its association with profit orientation, capital investment and the creation of new markets (Cantillon, 1755; Schumpeter, 1934).

\subsection{The term "entrepreneur" originates}

The term "entrepreneur" in English originates from the French verb "entreprendre" which means to undertake. It specifically refers to the establishment and management of business activity. There have been countless definitions of entrepreneurship and entrepreneurs. A direct quotation from Liu aptly summarizes the two terminologies.

\subsection{The main figure in the literature on entrepreneurship}

The study of entrepreneurship and its role in modern society has been fundamentally shaped by Joseph Schumpeter, who is considered as"the main figure in the literature on entrepreneurship" (Swedberg, 2000, p.12). Schumpeter defines the entrepreneur as someone who carries out new combinations in five different cases: (1) The introduction of a new

Copyright $\odot 2020$ Lei Shen

doi: 10.18282/le.v9i7.1492

This is an open-access article distributed under the terms of the Creative Commons Attribution Non-Commercial License

(http://creativecommons.org/licenses/by-nc/4.0/), which permits unrestricted non-commercial use, distribution, and reproduction in any medium, provided the original work is properly cited. 
good that is one with which consumers are not yet familiar or of a new quality of a good; (2) The introduction of a new method of production; (3) The opening of a new market; (4) The conquest of a new source of supply of raw materials or half-manufactured goods; and (5) The carrying out of the new organization of any industry, like the creation of a monopoly position of the breaking up or a monopoly position.

\subsection{Entrepreneurs assume many managerial roles}

The individuals whose function is to carry out these new combinations are called "entrepreneurs" (Schumpeter 1961:74). "entrepreneurship means the taking over and organization of some part of an economy, in which people's needs are satisfied through exchange, for the sake of making a profit and at one's own economic risk" (Swedberg, 2000:26; Douglas North, 1990:83). According to Hamilton (1994), before the eighteenth century, the term entrepreneur being used quite explicitly by Cantillon means "to buy the country produce from those who bring it or to order it to be brought on their account. They pay a certain price to resell wholesale or retail at an uncertain price". This explains an activity of independent commodity speculator. With the revolution of the industry, entrepreneurs began to assume many managerial roles to adjust to new requirements of raising capital, organizing production and distributing products.

\subsection{See the individual entrepreneur as "the agent of change"}

On the other hand, see the individual entrepreneur as "the agent of change" who responds to incentives embodied in the institutional framework. In a similar vein, Peter Drucker argues that "entrepreneurs see change as the norm and a healthy exercise. Usually, they do not bring about change themselves.

\subsection{Define entrepreneur and entrepreneurship}

The entrepreneur always searches for change, responds to it, and exploits it as an opportunity. The entrepreneur, by definition, shifts resources from areas of low productivity and yield to areas of high productivity and yield" (Drucker, 1999:23). Mark Casson defines the entrepreneur in the context of two conventional approaches, functional and indicative. The functional approach "specifies a certain function and deems anyone who performs this function to be an entrepreneur. The indicative approach describes an entrepreneur in terms of his legal status, his contractual relations with other parties and his position in society, and so on." In the light of the former approach, "an entrepreneur is someone who specializes in taking judgmental decisions about the coordination of scarce resources" (Casson, 2003:1920).

\section{Conclusion}

In the summary, R. Cantillon (1730) proposed a self-employed person with uncertain returns. Abbe Nicolas (1767) mentioned that a self-employed person is a leader of men, a manager of resources and an innovator. He is also said that a coordinator of production with managerial talent according to Jean Baptiste Say (1810). O. J. Schumpeter (1910) thought about that a self-employed person is also a creative innovator. F. Knight (1921) proposed that a manager is responsible for direction and control. E. Penrose (1959) discussed that a manager is a person who is able to identify opportunities and develop enterprises. J.E. Stepaneck (1960) talked about that a manager is a moderate risk-taker. D. C. McClelland (1961) posted that this person is also an achiever. R. Budner (1962) proposed that this person "has tolerance for ambiguity". O. Collins (1964) mentioned that a manager "has high need for autonomy" and that he has a "low need for support and conformity" according to W.D. Litzinger (1965). J.B. Rotter (1976) discussed that as a manager he is "individual with a locus of control" and a Type A behavior pattern according to J.A. Timmons (1985).

\section{References}

1. Adnan, Alias. Konsep Keusahawanan in Asas Keusahawan. Shah Alam Malaysian: Development Entrepreneurship Centre (MEDEC), Unit Percetakan ITM.1992.p.15-47.

2. Clarke,T.E. Review of the Status and Availability in Canadian Colleges and Universities of Courses or Programs Dealing with the Commercialization and Adoption of Science and Technology. Report for Industry, Science and Technology. Ottawa: Canada.2018.p.67-91.

3. Fauziah Sh. Ahmad and Rohaizat Baharun. Introducing Entrepreneurship Curriculum into Technical Disciplines: 
An Example from Malaysia. Adelaide: Small Enterprises Association of Australia and New Zealand-Adelaide Conference Proceedings.2012.p152-178.

4. Acs. Zoltan, Ed Glaeser and Robert Litan. Entrepreneurship and Urban Success: Toward a Policy Consensus. Ewing Marion Kauffman Foundation.2018;12(07):56-78.

5. Baumol, William J, Robert E. Litan, and Carl J. Schramm. Sustaining Entrepreneurial Capitalism. Capitalism and Society. 2017;22(02):1-36.

6. Best, Jill. Supporting the Public Library Entrepreneur. The Bottom Line: Managing Library Finances, 2010;14(03):132-144.

7. Blanchflower, David G. and Andrew J. Oswald, What Makes an Entrepreneur? Journal of Labor Economics, 1998;16(01):26-60.

8. Burke, Ronald J. and Macdermind, Graeme. A View of Their Economic Future: An Exploratory Study Among Recent Business School Graduates, Education and Training, 2009;41(01):14-19.

9. Breen, John and Bergin, Sue. Educating Entrepreneurs: Looking at Universities, Australia CPA, 2016;67(07):44-46.

10. Evans, David S. and Linda S. Leighton. Some Empirical Aspects of Entrepreneurship. The American Economic Review, 2009;79(03):519- 35.

11. Fairlie, Robert W.The Absence of the African American Owned RDD Business: An Analysis of the Dynamics of Self-employment. 2009;17(01):80-108.

12. Garrett, Thomas A. and Howard J. Wall. Creating a Policy Environment for Entrepreneurs. Cato Journal,2006;26(03): 525-552.

13. Gentry, William M. and R. Glenn Hubbard. Tax Policy and Entrepreneurial Entry. The American Economic Review,2000;90(02): 283-287.

14. Hurst, Erik and Annamaria Lusardi. Liquidity Constraints, Household Wealth, and Entrepreneurship. Journal of Political Economy,2004; 112(02):319-347.

15. Kreft, Steven F.and Russell S. Sobel. Public Policy, Entrepreneurship, and Economic Freedom. Cato Journal, 2005;25(03): 595-616.

16. Taniguchi, Hiromi. “Determinants of Women's Entry Into Self-employment. Social Science Quarterly, 2002;83(03):875-894. 